\title{
The depth distribution of recent marine Ostracoda from the southern Strait of Magellan
}

\author{
R. C. WHATLEY ${ }^{1}$, M. STAUNTON ${ }^{1}$ \& R. L. KAESLER ${ }^{2}$ \\ ${ }^{\prime}$ Micropalaeontology Unit, Institute of Earth Studies, University of Wales, Aberystwyth, Penglais, Aberystwyth, SY23 3DB, Wales, \\ UK. \\ ${ }^{2}$ Department of Geology, Paleontological Institute, and Museum of Invertebrate Paleontology, University of Kansas, Lawrence, \\ KA 66045-2911, USA.
}

\begin{abstract}
From 16 sediment samples collected from the Chilean part of the Strait of Magellan, 2338 Ostracoda were recovered. These represent 61 species belonging to 45 genera and 16 families. Previous work in the Tierra del Fuego Province has shown the faunas to be highly endemic, resulting from the relative isolation of the region and its particular climatic and oceanographical characteristics. The fauna of the Strait of Magellan is similar to those previously described with one notable exception: the occurrence of deep-water, psychrospheric species at shallow depths. Species of Bradleya, Agrenocythere, Poseidonamicus, Bythoceratina, and Legitimocythere, usually recorded from bathyal to abyssal depths of more than $1000 \mathrm{~m}$, were found together in the same samples with a typical, shelf fauna. Such unusual depth distribution of psychrospheric species may have resulted from the extremely cold temperature and low salinity of the water in the southern Strait of Magellan, coupled with the upwelling of cold, deep water masses. J. Micropalaeontol. 16(2): 121-130, October 1997
\end{abstract}

\section{INTRODUCTION}

The Strait of Magellan lies within the subantarctic region of the South Atlantic Ocean. This region has a northernmost limit of latitude $51^{\circ} \mathrm{S}$ and can be subdivided into two main provinces, the Chilean and the Magellanic. The ostracod faunas studied were collected from the latter province, which extends north to $42^{\circ} \mathrm{S}$ and comprises Tierra del Fuego, the Patagonian con- tinental shelf, and the Falkland Islands. The area sampled incorporates the southern end of the Strait of Magellan within the Tierra del Fuego region of southern Chile (Fig. 1).

Although the Argentine and Chilean continental shelves comprise one of the most extensive areas of continental shelf in the world, few publications prior to the 1960s discussed the benthic Ostracoda from this region and the western South

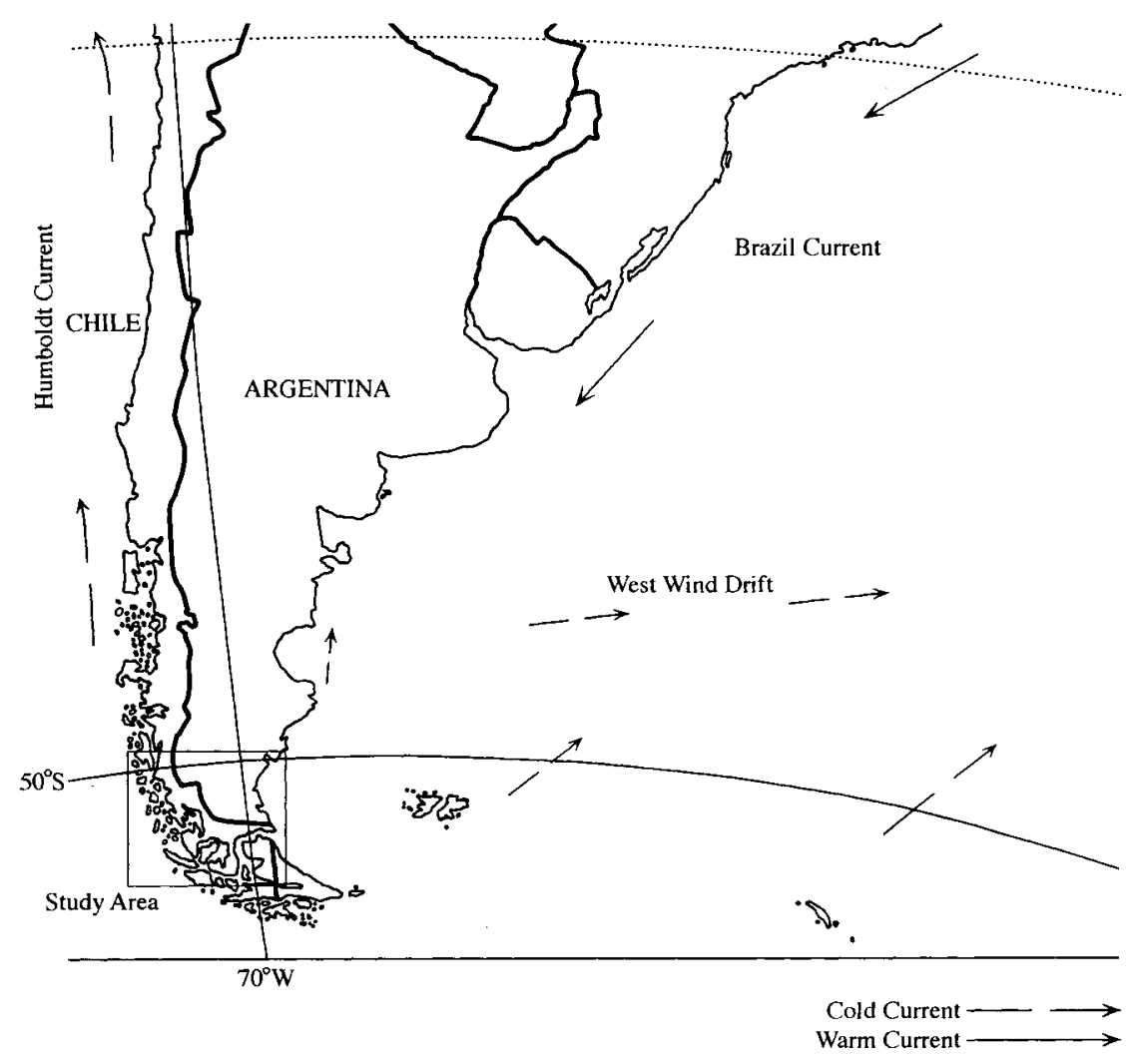

Fig. 1. Location of the study area and principal marine currents affecting the movement of water masses in southern South America. 


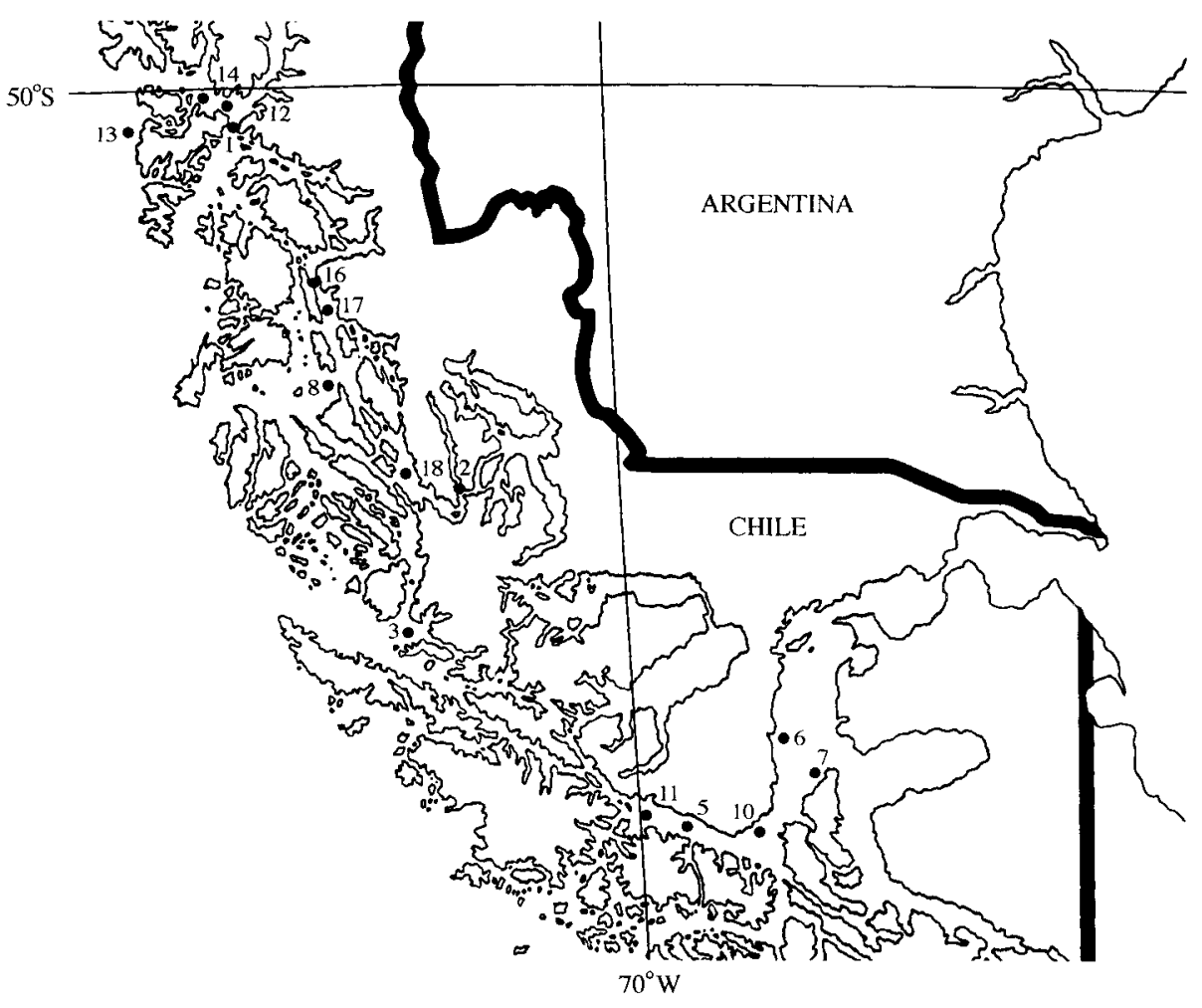

Fig. 2. Map of the Strait of Magellan indicating location of the 16 samples.

Atlantic and eastern South Pacific as a whole. The only early works available formed part of wider studies conducted by various researchers and research vessels such the HMS Challenger expedition to the South Atlantic (Brady, 1880) and Skogsberg's (1928) description of material collected by the Swedish Magellan expedition of 1896 and the Swedish Antarctic expedition of 1901 to 1903. Subsequent discussion of Ostracoda from the South Atlantic and Antarctic was quite limited until publications by Hartmann $(1987,1988,1989,1990,1991,1993)$ and Hartmann \& Hartmann-Schroeder (1962), Whatley \& Moguilevsky (1975), and Whatley et al. (1987, 1988, 1995, in press); however few publications have specifically discussed the marine Ostracoda of the Strait of Magellan. Kaesler et al. (1979) listed 33 species of Ostracoda from the northern part of the Strait in an analysis of the effects of petroleum pollution on the microfauna of the region.

\section{Methods}

Samples were collected in October 1969, by personnel of the University of Kansas and the Smithsonian Institution aboard the research vessel RV Hero. Sixteen samples of bottom sediment were collected from the southern part of the Strait of Magellan (Fig. 2) using either a Peterson grab or bolapipe dredge in shallow water and a Sanders epibenthic sled dredge to recover deeper-water sediments. The samples were collected at depths ranging from 2 to $916 \mathrm{~m}$. The sediments were processed at the University of Kansas before being sent to Aberystwyth, where the ostracod valves and carapaces were further sorted and identified. Sample sizes were variable (Table 1).

Analysis of hierarchical diversity was used in addition to the more traditional means of studying samples of modern sediments and their contained Ostracoda. Pielou (1966a, 1966b, 1966c, 1969) discussed in detail the use of indices of species diversity from information theory and recommended strongly the use of Brillouin's (1962) equation. Later (Pielou, 1975), pointed out that diversity may be partitioned hierarchically and that the components of the diversity at successively higher levels in the taxonomic hierarchy are additive and sum to the species diversity. This aspect of species diversity has not been widely used. Mulvany \& Kaesler (1976) presented a Fortran IV program for computing hierarchical diversities. Later, Kaesler \& Herricks (1979) applied the methodology in an investigation of the community structure of aquatic insects and fishes in polluted streams; and Kaesler \& Mulvany (1977) used hierarchical diversity to study communities of Ostracoda. Here, diversity has been partitioned into four, additive levels: superfamilial diversity, familial diversity, generic diversity, and species diversity. The superfamilial level also includes ostracods of the suborder Platycopina, which have typically been grouped only into families and suborders but not superfamilies.

\section{Ecology}

The Magellanic province in southern Chile lies along the Strait of Magellan to the east of the Andes and includes the Chilean part of Tierra del Fuego (Fig. 1). Although the climate is primarily subantarctic, the Strait of Magellan lies almost entirely 


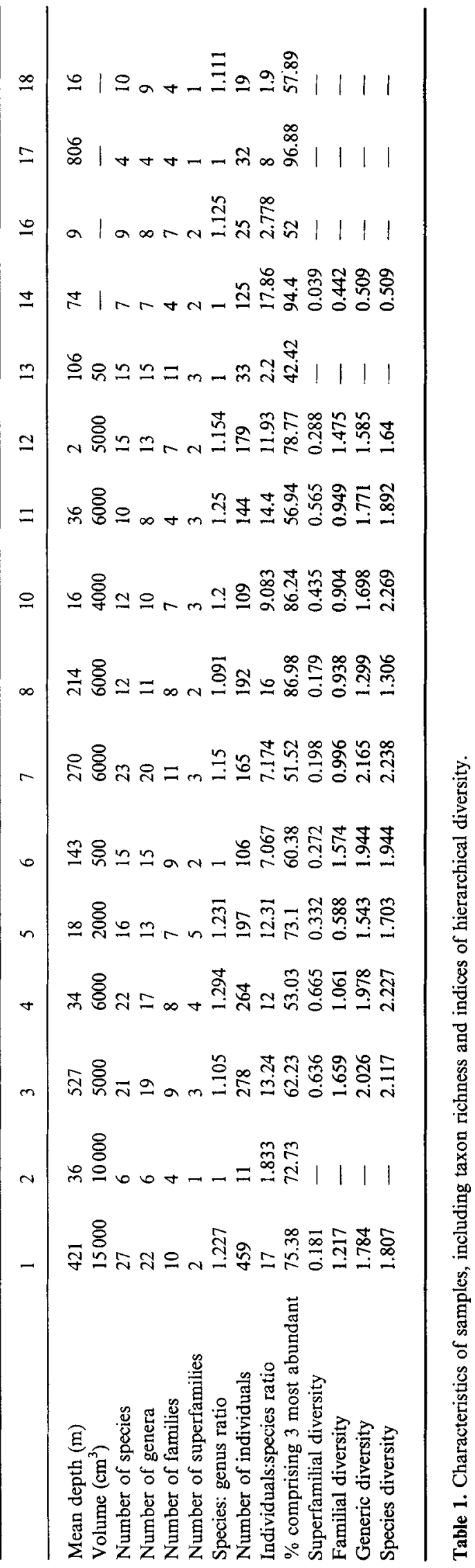




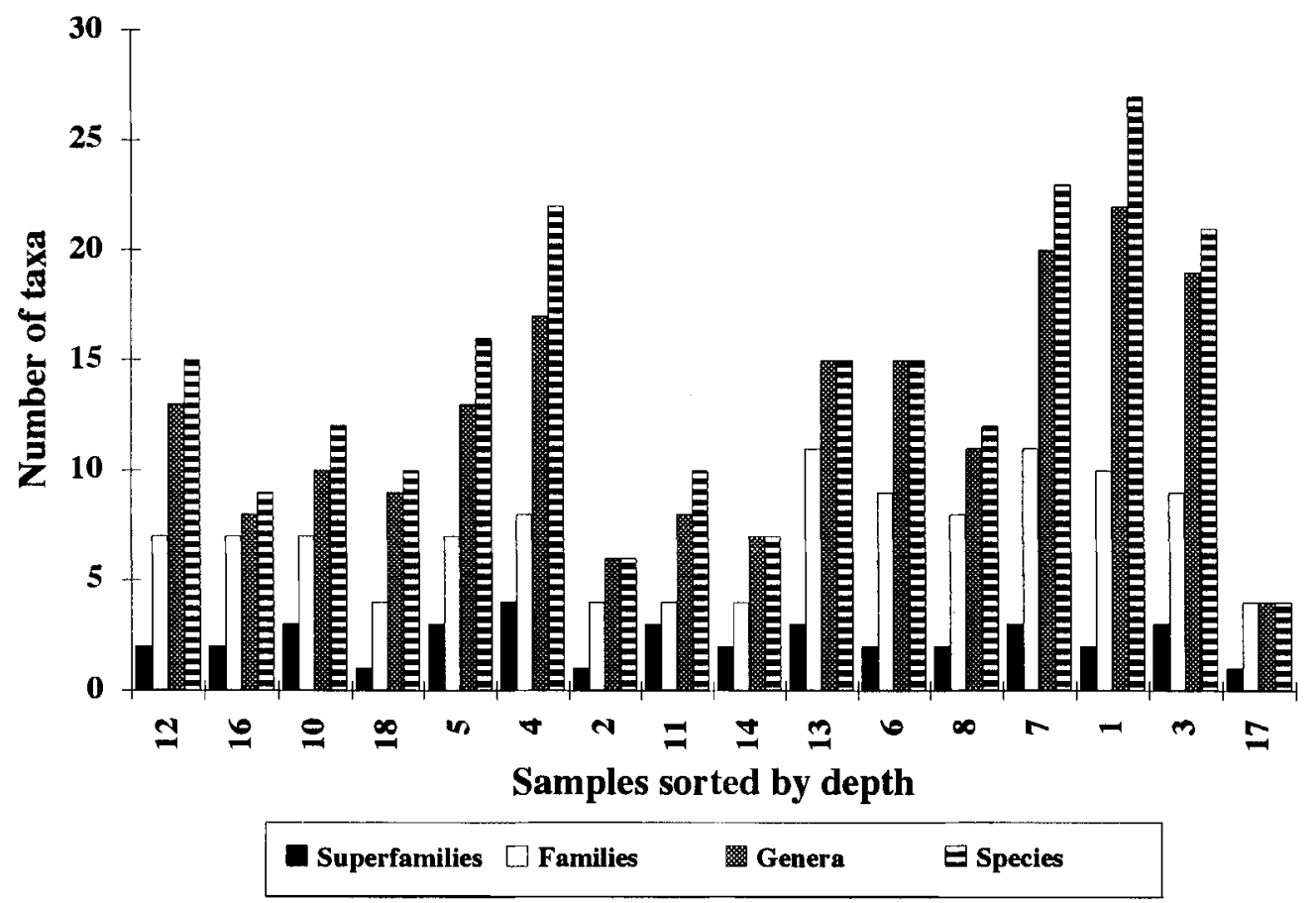

Fig. 3. Numbers of taxa of Ostracoda in the 16 samples studied. Samples have been sorted by depth. Sample 12 was collected in the shallowest water. Some dredged samples were collected over a range of depths. The value given throughout the study is the mean value. Number of superfamilies also includes ostracods of the suborder Platycopina, which is typically not divided into superfamilies.

\begin{tabular}{|c|c|c|c|c|c|c|c|c|c|c|c|c|c|c|c|c|}
\hline \multirow[t]{2}{*}{ Families } & \multicolumn{16}{|c|}{ Samples, sorted by depth } \\
\hline & 12 & 16 & 10 & 18 & $\mathbf{5}$ & 4 & 2 & 11 & 14 & 13 & 6 & 8 & 7 & 1 & 3 & 17 \\
\hline Bairdiidae & & $\mathrm{x}$ & $\mathrm{x}$ & & $\mathrm{x}$ & $\mathrm{x}$ & & $\mathrm{x}$ & $\mathrm{x}$ & $\mathrm{x}$ & & & $\mathrm{x}$ & $\mathrm{x}$ & $\mathrm{x}$ & \\
\hline $\begin{array}{l}\text { Bythocyprididae } \\
\text { Pontocyprididae }\end{array}$ & & & & & & & & & & $\mathrm{x}$ & & & & & & \\
\hline Bythocytheridae & & & & & & & & & & $\mathrm{x}$ & $\boldsymbol{\Lambda}$ & $x$ & & $\mathrm{x}$ & $\mathrm{x}$ & \\
\hline Cytherideidae & & & $\mathrm{x}$ & & $\mathrm{x}$ & & & & & & & & $\mathrm{x}$ & & & \\
\hline Cytheruridae & $\mathrm{x}$ & $\mathrm{x}$ & & $\mathrm{x}$ & $\mathrm{x}$ & $\mathrm{x}$ & $\mathrm{x}$ & & & $\mathrm{x}$ & $\mathrm{x}$ & $\mathrm{x}$ & $\mathrm{x}$ & $\mathrm{x}$ & $\mathrm{x}$ & \\
\hline Hemicytheridae & $\mathrm{x}$ & $\mathrm{x}$ & $\mathrm{x}$ & $\mathrm{x}$ & $\mathrm{x}$ & $\mathrm{x}$ & & $\mathrm{x}$ & & $\mathrm{x}$ & $\mathrm{x}$ & $\mathrm{x}$ & $\mathbf{x}$ & $\mathrm{x}$ & $\mathrm{x}$ & $\mathrm{x}$ \\
\hline Krithidae & & $\mathrm{x}$ & & & & & & $\mathrm{x}$ & $\mathrm{x}$ & & $\mathrm{x}$ & $\mathrm{x}$ & $\mathrm{x}$ & $\mathrm{x}$ & & $\mathrm{x}$ \\
\hline Leptocytheridae & $\mathrm{x}$ & & $\mathrm{x}$ & & $\mathrm{x}$ & $\mathrm{x}$ & & & & & $\mathrm{x}$ & & $\mathrm{x}$ & & & \\
\hline Loxoconchidae & $\mathrm{x}$ & & & & & & & & & $\mathrm{x}$ & $\mathrm{x}$ & & & $\mathrm{x}$ & $\mathrm{x}$ & $\mathrm{x}$ \\
\hline Paradoxostomatidae & & & & & & & & & & & & & & $\mathrm{x}$ & & \\
\hline Pectocytheridae & $\mathrm{x}$ & $\mathrm{x}$ & $\mathrm{x}$ & $\mathrm{x}$ & & $\mathrm{x}$ & $\mathrm{x}$ & & & $\mathrm{x}$ & $\mathrm{x}$ & $\mathrm{x}$ & $\mathrm{x}$ & $\mathrm{x}$ & $\mathrm{x}$ & \\
\hline Trachyleberididae & $\mathrm{x}$ & $\mathrm{x}$ & $\mathrm{x}$ & $\mathrm{x}$ & & & $\mathrm{x}$ & & $\mathrm{x}$ & $\mathrm{x}$ & $\mathrm{x}$ & $\mathrm{x}$ & $\mathrm{x}$ & $\mathrm{x}$ & $\mathrm{x}$ & \\
\hline Thaerocytheridae & & $\mathrm{x}$ & & & & & $x$ & & $\mathrm{x}$ & $\mathrm{x}$ & $\mathrm{x}$ & $\mathrm{x}$ & $\mathrm{x}$ & $\mathrm{x}$ & $\mathrm{x}$ & $\mathrm{x}$ \\
\hline Xestoleberidae & & & & & $\mathrm{x}$ & $\mathrm{x}$ & & & & & & & $\mathrm{x}$ & & & \\
\hline Cytherellidae & $\mathrm{x}$ & & & & $\mathrm{x}$ & $\mathrm{x}$ & & $\mathrm{x}$ & & $\mathrm{x}$ & & & $\mathrm{x}$ & & $\mathrm{x}$ & \\
\hline
\end{tabular}

Fig. 4. Distribution of ostracod families in the samples studied. Samples have been sorted by depth. Sample 12 was collected in the shallowest water.

within the southern hemisphere temperate zone. Climatic variations are common across the area, depending on variability of relief and proximity to the ocean. The land mass is divided into the Andes Mountains to the west and areas of low, flat, Tertiary rocks that bound the Atlantic seaboard to the east. To the north of the study area, southern Patagonia lies in a cool temperate zone of prevailing westerly winds and fairly frequent low-pressure storm systems. The area is typical of a cold, montane climate, characterized by continuously cool or cold weather with no warm season. This climate is controlled by the exposure to polar cyclones in the high latitudes of southern Chile. To the west of the mountains, precipitation reaches an annual maximum of $500 \mathrm{~cm}$, and temperatures average little more than $8^{\circ} \mathrm{C}$ in the summer and $3.8^{\circ} \mathrm{C}$ in the winter. Drier sites in the lee of the mountains, such as Punta Arenas (Fig. 2), may receive as little as $50 \mathrm{~cm}$ of rain annually (Collier et al., 1992).

The sampling area is confined to Boltovsky's (1968) zone four, the subantarctic zone, and extends from $50^{\circ} 9^{\prime} 55^{\prime \prime} \mathrm{S}$ (sample 1) 
to $53^{\circ} 56^{\prime} 0^{\prime \prime} \mathrm{S}$ (sample 10). The fauna of this zone was described as consisting entirely of cold-water or cold, temperate-water species. The waters are brought from high latitudes by the Cape Horn Current and its western branch, the Falkland Current. The Antarctic Circumpolar Current (west wind drift) and the Falkland Current bring cold, subantarctic waters to the Argentinian shelf. Offshore, parts of this current reach as far north as latitudes $34^{\circ}$ to $35^{\circ} \mathrm{S}$, but coastal areas are strongly influenced as far north as $32^{\circ} \mathrm{S}$. The surface temperature of the Falkland Current waters is usually between $6^{\circ} \mathrm{C}$ and $10^{\circ} \mathrm{C}$, and the salinity is between $33.5 \%$ and $34 \%$, but variation up to $18.5^{\circ} \mathrm{C}$ and $34.7 \%$ is common. North of $33.5^{\circ} \mathrm{S}$ in the summer and $34.5^{\circ} \mathrm{S}$ in the winter, the Falklands Current is present only on the bottom, but upwelling can occasionally bring it to the surface at lower latitudes.

\section{DISTRIBUTION OF OSTRACODA}

\section{General}

Sixty-one species of Ostracoda totaling 2338 individuals and belonging to 45 genera and 16 families were recovered from the 16 samples (Table 2). In all the samples, a high abundance of species is matched by high generic diversity. The genus:species ratio is approximately one for each sample. Familial diversity, however, is appreciably lower, as is to be expected (Table 1). The Hemicytheridae are the most common and diverse family, with at least one of 16 species found in 14 of the 16 samples (Fig. 4). The Cytheruridae, with 11 species present, and the Trachyleberididae, with eight species, were nearly equally abundant. Many families had few species, in particular, the Cytherellidae (1), the Pontocyprididae (1) and the Cytherideidae (1). Although few species of these families are present, individuals are sometimes quite abundant, in particular the Cytherellidae, which occur in seven samples (Fig. 4). Procythereis iganderssoni Skogsberg, 1928 (Hemicytheridae), the most common species, occurs in 11 of the 16 samples. Austroaurila theeli (Skogsberg, 1928) (Hemicytheridae) and Keijia falklandi (Brady, 1880) (Pectocytheridae), the next most widespread species, were found in nine samples, while several species occurred in six or seven samples. Using the depth zonation established by Whatley (1983), the environments from which samples were collected can be classified as littoral $(0-10 \mathrm{~m})$, shelf $(10-500 \mathrm{~m})$, or slope environments $(500-1000 \mathrm{~m})$. Most species were not abundant in samples from depths greater than $527 \mathrm{~m}$, with the exception of Bradleya dictyon (Brady, 1880); Krithe sp. cf. K. producta Brady, 1880; and Procythereis torquata Skogsberg, 1928 (Fig. 3).

\section{Littoral environment}

Two samples of fine sand and mud were collected from the littoral environment, sampies 12 and 16 . Both contained species belonging to the families Hemicytheridae, Cytheruridae, and Trachyleberididae (Fig. 4). Species of these three families common to the two samples were Procythereis iganderssoni, Austrotrachyleberis antarctica Neale, 1967, and Henryhowella sp. Sample 16 also contained members of the families Bairdiidae, Krithidae, Pectocytheridae, and Thaerocytheridae, while sample 12 , the shallowest sample, collected at a depth of only $2 \mathrm{~m}$, was slightly more diverse and included, in addition to the families mentioned above, members of the families Leptocytheridae, Loxoconchidae, and Cytherellidae but no species of the
Bairdiidae. While the Cytheruridae are typical of littoral environments, other characteristic littoral families, such as the Xestoleberididae and the Paradoxostomatidae, were absent from these samples.

\section{Shelf environments}

Twelve of the 16 samples investigated were collected from the continental shelf $(1,2,4-11,13,14$, and 18; no samples are numbered 9 or 15). These samples yielded all 61 species of Ostracoda representing 16 families including the Hemicytheridae, Cytheruridae, Trachyleberididae, Cytherideidae, Leptocytheridae, Bairdiidae, and Thaerocytheridae. All these families are common components of shelf faunas (Fig. 5). Most of the species identified, including Cytherella sp. 1 Whatley et al., 1995; Henryhowella dasyderma (Brady, 1880); Cativella bensoni Neale, 1967; Kuiperiana meridionalis (Müller, 1880); Australicythere devexa (Müller, 1908); Neonesidea sp. cf. N. australis (Chapman, 1914); and Austrotrachyleberis antarctica Neale, 1967, are known to inhabit shelf environments in the Patagonian region (N. Toy, pers. comm.; J. M. Chadwick, pers. comm). The shelf faunas were not diverse either at the generic or species level, with a maximum of 27 species and 22 genera being recorded in sample 1. Such low diversity may have resulted from the environmental conditions, namely the extremely cold water temperatures and lowered salinities that are common in the southern Strait of Magellan.

Depth also influenced the species distribution of Ostracoda on the continental shelf. Species richness, which is greatest between depths of 50 and $300 \mathrm{~m}$, decreases considerably below $400 \mathrm{~m}$, with most species not found below $527 \mathrm{~m}$ (Fig. 5). The distribution of some of the shelf species is strictly depth controlled, allowing three, broad, faunal depth ranges to be identified. The first depth range is occupied by the shallow-shelf species that are confined to less than $50 \mathrm{~m}$, including Australicytheridea dispersapunctata Whatley et al., 1987; Austroaurila impluta (Brady, 1880); Bairdopillata hirsuta (Brady, 1880); Hemicytherura stationis (Müller, 1908); Leptocythere mosleyi (Brady, 1880); Argilloecia sp. cf. A. meridionalis (Chapman, 1914); and species of the superfamily Bairdiacea, with the exception of Bairdopillata sp. cf. B. simplex (Brady, 1880). The second depth is occupied by species that range from less than $50 \mathrm{~m}$ to approximately $500 \mathrm{~m}$, including Austroaurila theeli, Austrotrachyleberis antarctica, Falklandia ephippiata (Skogsberg, 1928), and Kuiperiana meridionalis. The final depth zone is occupied by species that range from shallow-shelf to slope environments, such as Bradleya dictyon, Krithe sp. cf. $K$. producta, and Procythereis torquata (Fig. 5).

\section{Continental slope environment}

One sample was collected from this zone at a depth of 696 $916 \mathrm{~m}$ from a muddy substrate. Only four species were present, giving this locality the lowest species and generic richness in the study (Table 1). As would be expected at such depths, two psychrospheric species were present, Bradleya dictyon and Krithe sp. cf. K. producta.

\section{Psychrospheric fauna}

Such genera as Poseidonamicus, Bradleya, and Agrenocythere were termed psychrospheric by Benson \& Sylvester-Bradley 


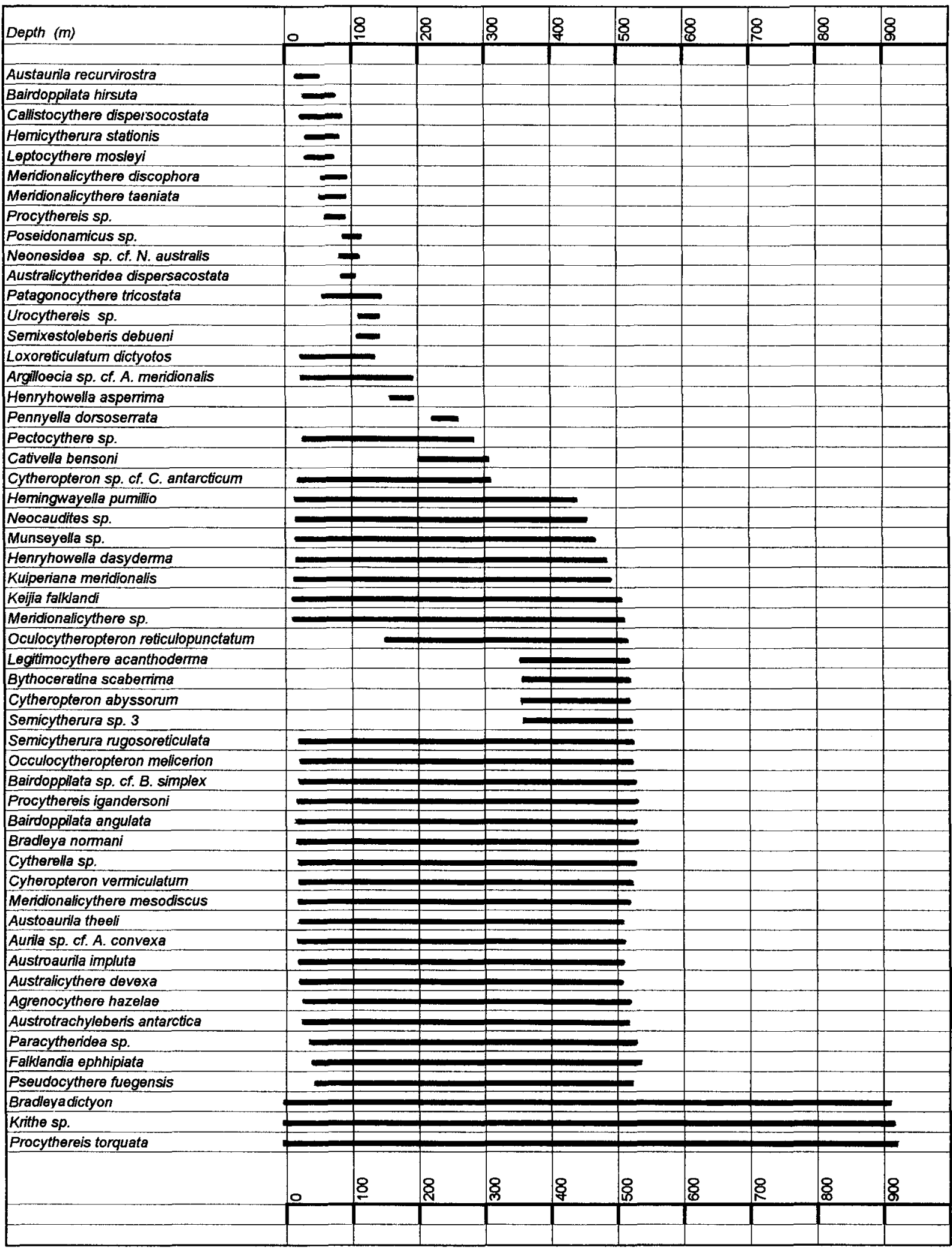

Fig. 5. Depth distribution of species of Ostracoda in the Strait of Magellan. 
Bairdoppilata angulata (Brady, 1880)

Bairdoppilata hirsuta (Brady, 1880)

Bairdoppilata sp cf. B. simplex (Brady, 1880)

Neonesidea sp. cf. $N$. australis (Chapman, 1914)

Bythocypris sp.

Argilloecia sp. cf. A. meridionalis (Chapman, 1914).

Pseudocythere fuegensis Brady, 1880

Australicytheridea dispersopunctata Whatey et al., 1987

Cytheropteron abyssorum Brady, 1880

Cytheropteron sp. cf. C. antarcticum Chapman, 1916

Cytheropteron vermiculatum Whatley et al., 1988

Hemicytherura stationis (Müller, 1908)

Hemingwayella pumilio (Brady, 1880)

Loxoreticulatum dictyos Whatley et al., 1988

Oculocytheropteron melicerion Whatley et al., 1988

Oculocytheropteron reticulopunctatum Whatley et al., 1988

Paracytheridea sp Whatley et al., 1987

Semicytherura rugosoreticulata Whatley et al., 1988

Semicytherura sp. 3 Whatley et al., 1987

Patagonacythere tricostata Hartmann, 1962

Australicythere devexa (Müller, 1908)

Austoaurila impluta (Brady, 1880)

Austroaurila recurvirostra (Skogsberg, 1928)

Austroaurila theeli (Skogsberg, 1928)

Aurila sp. cf. A. convexa (Baird, 1850)

Falklandia ephippiata (Skogsberg, 1928)

Meridionalicythere discophora (Skogsberg, 1928)

Meridionalicythere mesodiscus (Skogsberg, 1928)

Meridionalicythere taeniata (Skogsberg, 1928)
Meridionalicythere sp. Whatley et al., 1988

Neocaudites sp.

Procythereis iganderssoni Skogsberg, 1928

Procythereis torquata Skogsberg, 1928

Procythereis sp.

Krithe sp.

Callistocythere dispersocostata Hartmann, 1962

Leptocythere mosleyi (Brady, 1880)

Leptocythere sp.

Kuiperiana meridionalis (Mller, 1880)

Loxoconcha sp.

Pellucistoma sp. 1

Keijia falklandi (Brady, 1880)

Munseyella sp.

Pectocythere sp.

Agrenocythere hazelae (van den Bold, 1946)

Austrotracyleberis antarctica (Neale, 1967)

Cativella bensoni Neale, 1967

Henryhowella asperrima (Reuss, 1850)

Henryhowella dasyderma (Brady, 1880)

Henryhowella sp.

Legitimocythere acanthoderma (Brady, 1880)

Pennyella dorsoserrata (Brady, 1880)

Bradleya dictyon (Brady, 1880)

Bradleya normani (Brady, 1880)

Poseidonamicus sp.

Semixestoleberis debueni Hartmann, 1962

Xestoleberis sp.

Cytherella sp. 1

Table 2. Ostracod species found in the southern part of the Strait of Magellan.

(1971) because they inhabit cold, deep water that is at temperatures below $8-10^{\circ} \mathrm{C}$. Deep-water, psychrospheric faunas are less diverse than their shallow-water counterparts, and individuals are usually larger and rarer than those of shallowwater environments (Benson, 1984). Furthermore, a common characteristic of these faunas is their tendency to become sightless at depths greater than $600 \mathrm{~m}$ (Benson, 1972). At 12 sampling sites in the study area, blind psychrospheric species including Bythoceratina scaberrima (Brady, 1886); Bradleya dictyon; Bradleya normani (Brady, 1880); Agrenocythere hazelae (van den Bold, 1946); Legitimocythere acanthoderma (Brady, 1880); Poseidonamicus sp. (Whatley et al., in press); and Henryhowella asperrima (Reuss, 1850), were found inhabiting shelf environments alongside shallow-water taxa (Fig. 6).

\section{Hierarchical diversity}

The advantages of computing indices of species diversity from information theory are twofold. First, an index of diversity combines information on the number of taxa and the evenness with which individuals are distributed among taxa, providing better insight into the structure of the community than species richness alone. Second, the index is not tied to the occurrence of specific taxa. Thus it allows two or more samples to be compared with respect to their community structure even when they have no species in common.

Figure 7 shows the results of partitioning species diversity among four categories in the taxonomic hierarchy. Indices of species diversity were computed for only eleven of the sixteen samples. Samples that yielded fewer than 100 ostracods were excluded because Brillouin's (1962) index is dependent on sample size.

Species diversity, the uppermost broken line in Fig. 7, was nearly steady across the study area, typically ranging from about 1.6 to 2.3. A pronounced exception to this generalization is the species diversity of sample 14 , which is only 0.509 . Sample 14, collected at a depth of $74 \mathrm{~m}$, yielded 125 ostracod specimens but only seven species. This species richness was lower than that of any other samples except for samples 2 and 17 (Table 1). The low species richness of these two samples is no doubt related to their low overall yield of ostracods, 11 and 32 individuals, respectively. Of the 125 specimens from sample 14, 106 were Bradleya dictyon, a characteristically deep-water species. The unevenness of the distribution of individuals among species and the small number of other species (6) contributed to the low species diversity. Some characteristic of the environment, perhaps low oxygen, kept typically shallow-water ostracods out of the sample but did not prevent $B$. dictyon from proliferating.

Generic diversity closely tracks and in some samples is exactly equal to species diversity. This results when the numbers of species and genera in a sample are the same. With a few notable exceptions, familial diversity more or less bisects the distance between the curves of generic and superfamilial diversity. Sample 14 has a familial diversity only slightly less than the generic and species diversity. The superfamilial diversity of sample 14 is 0.039 , the result of its having only one specimen that is not in the superfamily Cytheracea, a single specimen of Bairdoppilata sp. cf. B. simplex. Because of the abundance of psycrospheric species throughout the study area, the diversities 
at all levels generally increase with depth from the low values of sample 14 collected at a depth of $74 \mathrm{~m}$.

\section{DISCUSSION}

The fauna displays several important characteristics. The species are small, very abundant, and, importantly, most are sighted. Apart from the low species and generic richness mentioned above, the traits of the fauna are not characteristic of deep water. Despite the obvious shelf nature of the fauna, psychrospheric species of Ostracoda were recorded from 12 sampling sites in the area. Sample 1 had six psychrospheric species comprising $86 \%$ of the ostracod fauna, most of which were present as adults, apart from Agrenocythere hazelae, which was recovered only as instars. Sample 3 had four psychrospheric species, comprising $29 \%$ of the fauna, including a single valve of Bythoceratina scaberrima, a rare element in the deep sea that is characteristic of depths from 1000 to $3000 \mathrm{~m}$. Six psychrospheric species were recovered from sample 8, including Agrenocythere hazelae (the dominant species comprising $57 \%$ of the fauna) and Henryhowella asperrima, which accounted for $10 \%$ of the total fauna. The other four species comprised $24 \%$. Bradleya normani and Henryhowella dasyderma occur in sample 13, forming about $3 \%$ of the total population. Five psychrospheric species occurred in sample 14. Bradleya dictyon formed $85 \%$ of the total population, while the other species accounted for $11 \%$. This sample is unique among the 16 samples: its fauna comprised almost entirely psychrospheric species. Sample 16 contained three of these deep-water species forming $28 \%$ of the fauna, while sample 17 , the only truly deep-water sample (collected from 696 to $916 \mathrm{~m}$ ), provided specimens of Bradleya dictyon and Krithe sp. cf. $K$. producta, the latter comprising $87 \%$ of the ostracod fauna.

The relative abundance of a species varied greatly between samples. Poseidonamicus sp. and Pennyella dorsoserrata (Brady, 1880) were recovered only as single valves, while Bythoceratina scaberrima yielded just two adult valves. Other species, such as Agrenocythere hazelae, while dominating the faunas in which they were recorded, were not distributed widely, having been found at only two sites. Similarly, Legitimocythere acanthoderma was a dominant species in sample 1 but was not found elsewhere in the study area. Henryhowella asperrima, which was found only in sample 8 , comprised $10 \%$ of the fauna. Elsewhere, Henryhowella dasyderma and a new species of Henryhowella were the common species of Henryhowella encountered. By far the three most abundant psychrospheric species were Krithe sp. cf. $K$. producta, Bradleya normani, and Bradleya dictyon. Bradleya normani, which was recovered from five samples, was the dominant species at sites 1 and 16. Bradleya dictyon was extremely abundant in the two samples from which it was recorded, and, finally, Krithe sp. cf. $K$. producta formed a high percentage of the total fauna of six of the samples examined.

The depth ranges recorded for the psychosperic species in this study are illustrated in Figs 5 and 6 . It has been mentioned previously that deep-water species occur at relatively shallow depths in this region, due to the low water temperatures in the area, which is influenced by cold, polar currents. For example, Chadwick (unpublished MSc thesis, Aberystwyth, 1986) recorded Bradleya normani and Henryhowella dasyderma at shallower depths than previously reported. Benson (1974) stated that Bradleya dictyon is generally restricted to water depths in excess of $1750 \mathrm{~m}$, yet this species is recorded at $74 \mathrm{~m}$ (site 14) in the southern Strait of Magellan. Furthermore, the genera Agrenocythere, Bradleya, and Poseidonamicus usually only occur at abyssal depths (Benson, 1974). Agrenocythere is considered typical of depths of about $1500 \mathrm{~m}$ (Benson, 1972) but has been discovered at depths as great as $2957 \mathrm{~m}$ (Benson and Peypouquet, 1983). Poseidonamicus species are normally found between 2500 and $4000 \mathrm{~m}$ depth with the exception of a sighted species of Poseidonamicus discovered living on the continental and upper slope of southwestern Africa (Whatley \& Dingle, 1989). Species belonging to both genera were identified in the study area in the samples collected as shallow as $36 \mathrm{~m}$ depth and occur with typical shelf species. Coles \& Whatley (1989) have recorded Legitimocythere at depths of $5725 \mathrm{~m}$ in the North Atlantic, but there have been occasional recordings from Recent environments as shallow as $341 \mathrm{~m}$ (Cronin, 1983). Legitimocythere acanthoderma has been recorded at a depth of $2515 \mathrm{~m}$ (Brady, 1880), $3175 \mathrm{~m}$ (Benson, 1974) from DSDP Site 356 , and $2086 \mathrm{~m}$ (Ducasse and Peypouquet, 1979) from DSDP Site 43. This species was found at a depth of $456 \mathrm{~m}$ in the Strait of Magellan. The deep-water species Bradleya normani and $B$. dictyon, which are commonly used to identify abyssal assemblages, were also recorded at shallower depths than usual $(9.3 \mathrm{~m}$ for Bradleya normani and $74 \mathrm{~m}$ for $B$. dictyon).

Upwelling is particularly common on the western sides of continents. This phenomenon seemingly operates in the area of the Strait of Magellan studied and impacts the environment. Upwelling of deep, cold water masses probably resulted in the occurrence of these blind, deep-water genera on the continental shelf of the Strait of Magellan. Apart from the effect of upwelling on the depth distribution of the psychrospheric species, the specialized environmental conditions existing in the study area may have been influential, too. Continuous cold weather caused by exposure to polar cyclones results in a very low annual temperature range of $3.8-8^{\circ} \mathrm{C}$. Water temperatures are also extremely low due to the influence of polar currents, and salinity is usually from 33.5 to $34 \%$. Such extremes of

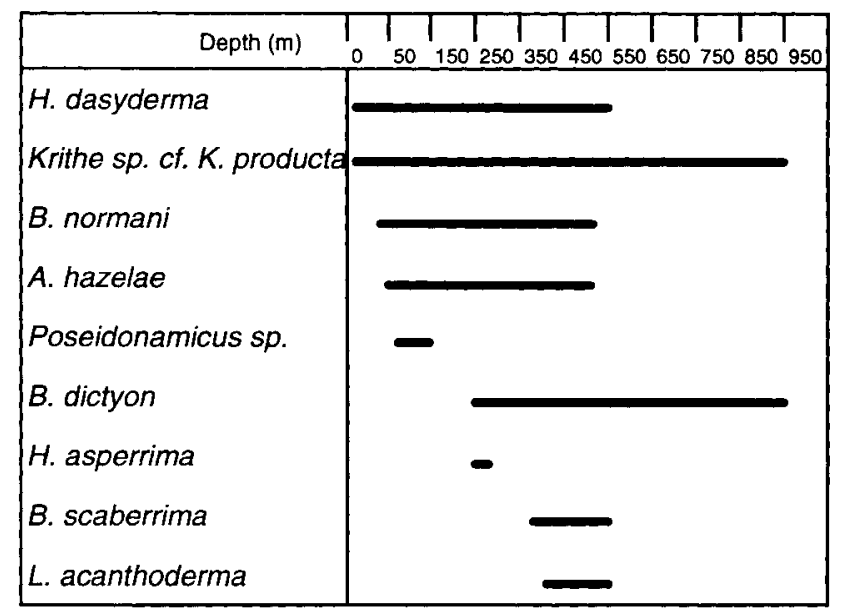

Fig. 6. Depth distribution of psychrospheric Ostracoda in the Strait of Magellan. 
Recent marine ostracoda

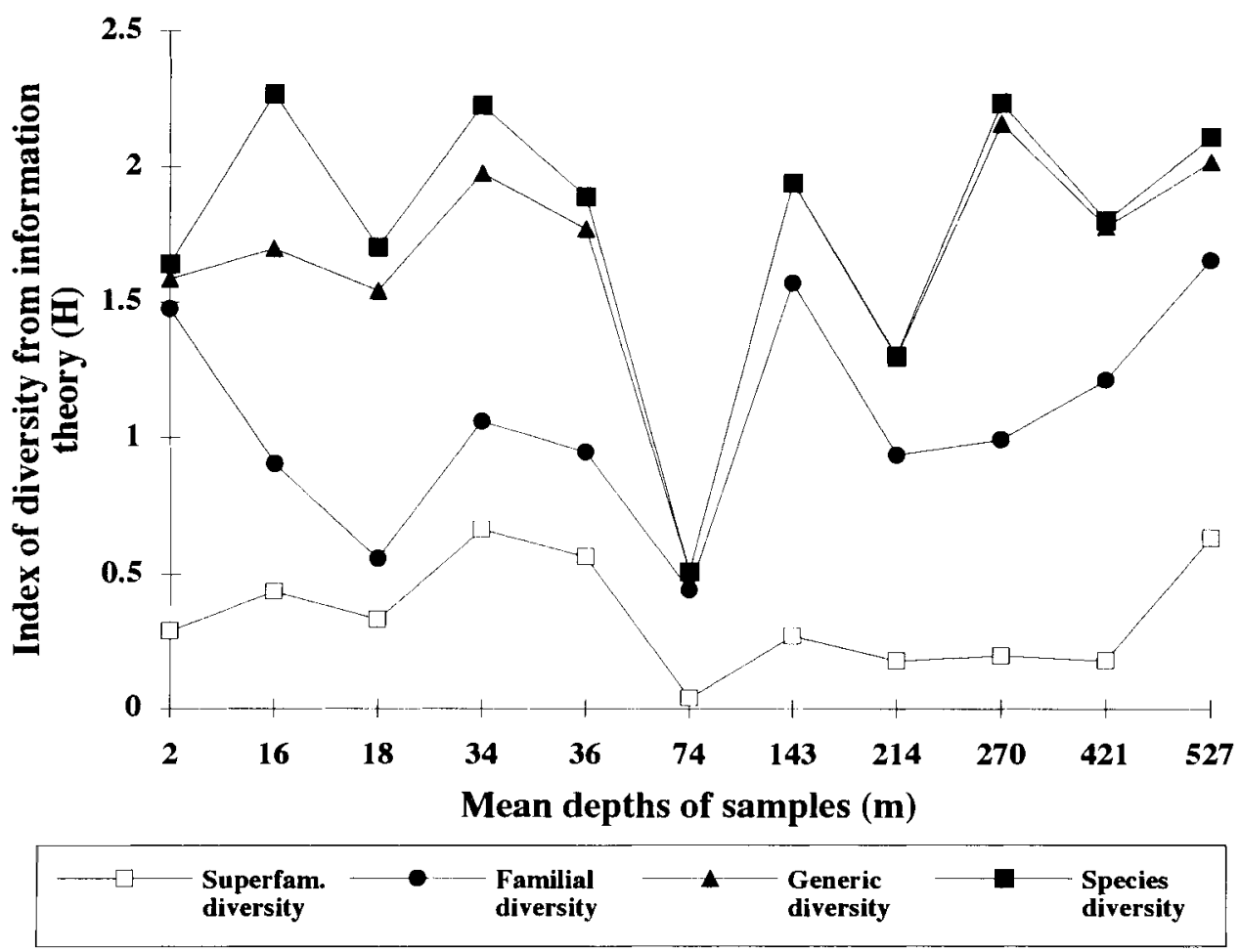

Fig. 7. Additive, hierarchical components of diversity from information theory resolved into four levels of the taxonomic hierarchy: superfamilies, families, genera, and species. Superfamilial diversity also includes ostracods of the suborder Platycopina, which is typically not divided into superfamilies.

temperature may have resulted in an environment in which it is possible for psychrospheric species to exist at much shallower depths than normal.

\section{ACKNOWLEDGEMENTS}

MS acknowledges A. Moguilevsky, N. Toy, and I. Boomer for their assistance in the preparation of this manuscript. All the authors are grateful to R. H. Benson, J. Merida, J. Winslow, and the captain and crew of the RV Hero for their assistance in the field and to Jane Priesner of the Paleontological Institute for her assistance with illustrations. The research was made possible in part by support of National Science Foundation grants GA12472 and GV-25157 to The University of Kansas (RLK, principal investigator).

\section{Manuscript received September 1994 Manuscript accepted February 1995}

\section{REFERENCES}

Benson, R. H. 1972. The Bradleya problem, with descriptions of two new psychrospheric ostracode genera, Agrenocythere and Poseidonamicus (Ostracoda: Crustacea). Smithsonian Contributions to Paleobiology, 12: $1-138$.

Benson, R. H. 1974. Preliminary report on the ostracodes of Leg 24. Initial Reports of the Deep Sea Drilling Project, 24: 1037-1043.

Benson, R. H. 1984. Estimation of greater palaeodepths with ostracodes, especially in past thermospheric oceans. Palaeogeography, Palaeoctimatology, Palaeoecology, 48: 107-141.

Benson, R. H. \& Peypouquet, J. P. 1983. The upper and Mid Bathyal Cenozoic ostracode faunas of the Rio Grande Rise found on Leg 72 DSDP. Initial Reports of the Deep Sea Drilling Project LXXII: 805818. US Government Printing Office, Washington, D.C.
Benson, R. H. \& Sylvester-Bradley, P. C. 1971. Deep-sea ostracodes and the transformation of ocean to sea in the Tethys. Bulletin du Centre du Recherches PAU-Société Nationale des Pétroles d'Aquitaine, 5: 63-91. Boltovsky, E. 1968. Hidrología de las Aguas Superficiales en la Parte Occidental del Atlántico sur. Museo Argentino de Ciencias Naturales, Hidrobiología, II: 199-224.

Brady, G. S. 1880 . Report on the Ostracoda dredged vby the H.M.S. Challenger during the years 1873-1876. Report of the Voyage of H.M.S. Challenger, Zoology, 1: 1-184, plates 1-43.

Brillouin, L 1962. Science and Information Theory. Academic Press, New York, $347 \mathrm{pp}$.

Coles, G. \& Whatley, R. C. 1989. Palaeocene to Miocene genera and species of Ostracoda from DSDP Sites in the North Atlantic. Revista Española de Micropaleontologia, 21: 81-124.

Collier, S., Skidmore, T. E. \& H. Blakemore, H. (eds) 1992. The Cambridge Encyclopaedia of Latin America and the Caribbean, 2nd edn. Cambridge University Press, 320 pp.

Cronin, T. 1983. Bathyal ostracods from the Florida-Hatteras slope, the Straits of Florida and the Blake Plateau. Marine Micropaleontology, 8: 89119.

Ducasse, O. \& Peypouquet, J. P. 1979. Cenozoic ostracods: their importance for bathymetry, hydrology and biogeography. Initial Reports of the Deep Sea Drilling Project, XLVII: 343-363.

Hartmann, G. 1987. Antarktische Benthische Ostracoda XI. Auswertung der Fahrten der 'Polarstern' Ant. III/2 und der Reisen der 'Walther Herwig' 68/1 und 2. 2. Teil: Elephant Island und Brandsfieldstrabe. Mitteilungen Hamburg Zoologisches Museum und Institut, 84: 115-156.

Hartmann, G. 1988. Antarktische Benthische Ostracoda III. Auswertung der Reise der Polarstern Ant. VI-2. Mitteilungen Hamburg Zoologisches Museum und Institut, 85: 141-167.

Hartmann, G. 1989. Antarktische Benthische Ostracoda IV. Auswertung der Reise der Polarstern Ant. VI-2. Mitteilungen Hamburg Zoologisches Museum und Institut, 86: 209-230.

Hartmann, G. 1990. Antarktische Benthische Ostracoda VI. Auswertung der Reise der 'Polarstern' Ant. VI-2 sowic Versuch einer vorlöufigen Auswertung aller bislang vorliegenden Daten. Mitteilungen Hamburg Zoologisches Museum und Institut, 87: 191-245. 
Hartmann, G. 1991. Antarktische Benthische Ostracoda VII. Ostracoden Aus dem Oberon Litoral von King George Island. Mitteilungen Hamburg Zoologisches Museum und Institut, 88: 209-230.

Hartmann, G. 1993. Antarktische Benthische Ostracoda IX. Ostracoden Von der Antarktischen Halbinsel und Von der Isla de Los Estados (Fuerland/Argentinien). Mitteilungen Hamburg Zoologisches Museum und Institut, 90: 227-237.

Hartmann, G. \& Hartmann-Schroder, G. 1962. Zur Kenntnis des Eulittorals der Chilenischen Pazifikküste und der Argentinischen Küste Sud Patagoniens unter Besonder Berucksichtigung der 'Polychaetes und Ostracoda'. Teil III. Ostracoden des Eulittorals. Mitteilungen Hamburg Zoologisches Museum und Institut. Erganzungband zu band, 60: 169-270.

Kaesler, R. L. \& Herricks, E. E. 1979. Hierarchical diversity of communities of aquatic insects and fishes. Water Resources Bulletin, 13: $1117-1125$.

Kaesler, R. L. \& Mulvany, P. S. 1977. Approaches to the diversity of assemblages of Ostracoda, 33-42. In Löffler, H. \& Danielopol, D. (Eds) Aspects of Ecology and Zoogeography of Recent and Fossil Ostracoda. Junk, The Hague.

Kaesler, R. L., Smith, S. \& Whatley, R. C. 1979. Ostracoda and petroleum pollution in the Strait of Magellan, 237-247. In Krstic, N., (Ed) Taxonomy, Biostratigraphy and Distribution of Ostracodes. Proceedings of the VII International Symposium on Ostracoda, Serbian Geological Society, Belgrade.

Mulvany, P. S. \& Kaesler, R. L. 1976. Fortran IV program to compute hierarchical diversity. Computers \& Geosciences, 2: 521-529.

Pielou, E. C. 1966a. Shannon's formula as a measure of specific diversity: its use and misuse. American Naturalist, 100: 463-465.

Pielou, E. C. 1966b. Species-diversity and pattern-diversity in the study of ecological succession. Journal of Theoretical Biology, 10: 370-383.
Pielou, E. C. 1966c. The measurement of diversity in different types of biological collections. Journal of Theoretical Biology, 13: 131-144.

Pielou, E. C. 1969. An Introduction to Mathematical Ecology. WileyInterscience, New York, $286 \mathrm{pp}$.

Pielou, E. C. 1975. Ecological Diversity. Wiley-Interscience, New York, $165 \mathrm{pp}$.

Skogsberg, T. 1928. Studies on marine ostracods, Part II. External morphology of the genus Cythereis, with descriptions of 21 new species. California Academy of Sciences Occasional Paper, 15: 1-155.

Whatley, R. C. 1983. Some aspects of the palaeobiology of Tertiary deep sea Ostracoda from the south west Pacific. Journal of Micropalaeontology, 2: 83-104.

Whatley, R. C. \& Dingle, R. V. 1989. First record of extant sighted shallow water species of the genus Poseidonamicus Benson from the continental margin of south west Africa. Annals of the South African Museum, 98: 437-457.

Whatley, R. C., Chadwick, J., Coxill, D. \& Toy, N. 1987, New genera and species of cytheracean Ostracoda from the south west Atlantic. Journal of Micropalaeontology, 6: 1-12.

Whatley, R. C., Chadwick, J., Coxill, D. \& Toy, N. 1988. The ostracod family Cytheruridae from the Antarctic and south west Atlantic Revista Española de Micropaleontologia, 20: 171-203.

Whatley, R. C. \& Moguilevsky, A. 1975. The family Leptocytheridae in Argentine waters. Bulletin American Paleontology, 65: 501-527.

Whatley, R. C., Toy, N., Moguilevsky, A. \& Coxill, D. 1995. Ostracoda from the south west Atlantic. Part 1. The Falkland Islands. Revisto Española de Micropaleontologia, 27, 17-38.

Whatley, R. C., Moguilevsky, A., Toy, N., Chadwick, J. M. \& Ramos, M. I. F. in press. Ostracoda from the SW Atlantic Part II. The littoral fauna from between Tierra del Fuego and the Rio de la Plata. Revisto Española de Micropaleontologia, 29. 